\title{
Carbon Emissions from Indian Power Sector- A Roadmap towards Environmental Sustainability
}

\author{
Oum Kumari R, Nupur Ojha
}

\begin{abstract}
Energy poverty was once considered as the major bottleneck for development of an economy. But now it is not scarcity which is an issue, but affluence as rightly said by Galbraith. According to him as a society becomes affluent, the problems like pollution, environmental degradation, global warming etc. takes place. Hence now the emphasis should not be on "how to overcome the problem of scarcity" but on "how to reduce the adverse effects on environment caused due to growth and development". Therefore, it is being accepted worldwide that environmental sustainability is threatened by affluence and not by scarcity. Of all the requirements of humans today, electricity occupies a special importance, and this is the reason that the consumption of electricity is considered as an effective parameter of growth and development. The more is the consumption of power the more would be the growth taking place in the economy. In the past few decades almost all the economies whether developed, developing or underdeveloped have been working hard towards achieving self-sufficiency in power. Even in India the consumption of power has increased manifold i.e. from $734 \mathrm{KWh}$ in 2008-09 to $1075 \mathrm{KWh}$ in 2015-16 i.e. $46 \%$ increase in 8 years (CEA). The positive outcome of this effort is the improvement in the quality of human population in the past few decades but the fact about this rise in consumption of power is it has resulted in various environmental issues in India as even today more than $70 \%$ of power needs is met from fossil fuels. The present article presents the scenario of Indian power sector since independence in section I. Relationship between CO 2 emissions, Power sector and growth using Environment Kuznets Curve (EKC) is discussed in section II and some strategic measure to take the economy from economic development to environmental sustainability is given based on findings in the final section of the article.
\end{abstract}

Key Words: Economic Development, Environment Sustainability, Power Consumption, Carbon Emissions

\section{I.I INDIAN POWER SECTOR-AN OVERVIEW}

Electricity or any other source of energy has a vital role in the growth of the economy as all the economic activities are possible only with the use of power. Electricity consumption and economic development are interrelated to one another as one leads to another. Most of the economies today consider per capita consumption of power as one of the most important indicators to measure growth, i.e. higher the consumption, higher is the growth. In India the per capita consumption of power has multiplied many times as it is clear from the graph below figure 1.1. The per capita consumption of electricity was mere $50 \mathrm{KW}$ at the time of independence which has now increased to $1200 \mathrm{KWh}$ which is a strong indicator of growth. But this increase in the consumption of power has led to serious issues like power deficit (demand for power more than

Revised Version Manuscript Received on 16 September, 2019.

Dr Oum Kumari R, oum.kumari@jaipur.manipal.edu, Manipal University Jaipur Jaipur. the supply) as shown in figure 1.2 and environmental degradation. In order to meet out the growing demand for electricity, Ministry of finance has been striving hard to raise the installed capacity accordingly and in the past 6 decades our installed capacity has increased from mere $2500 \mathrm{MW}$ to more than $300000 \mathrm{MW}$. India today is Fourth largest in terms of energy production but this growth in the installed capacity also has aggravated the problem of fiscal deficit as ministry of finance is forced to borrow funds to increase installed capacity and keep pace with ever increasing demand for power.

Figure 1.1: Growth in the Consumption of Power (2000-2018)

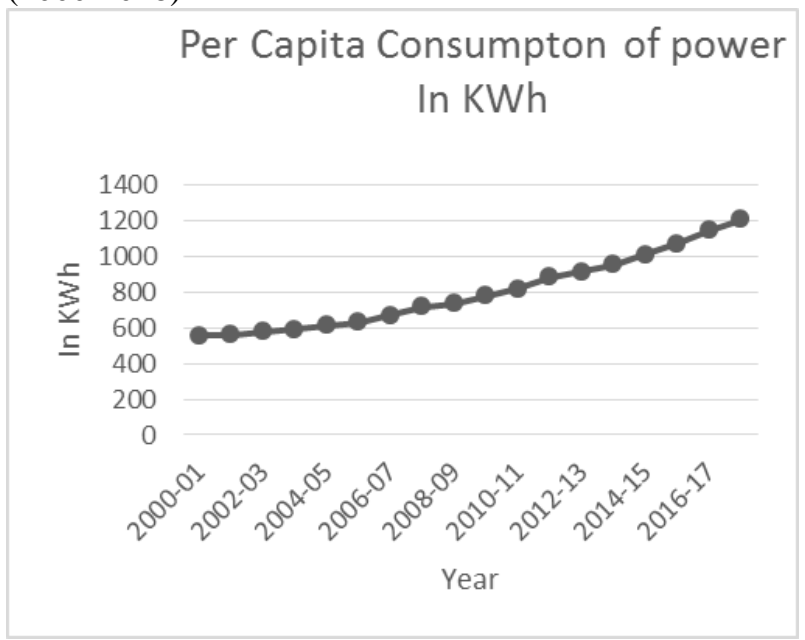

Source: Central Electricity Authority (CEA)

Figure 1.2: Growing Power Crisis in India

\section{Power Deficit}

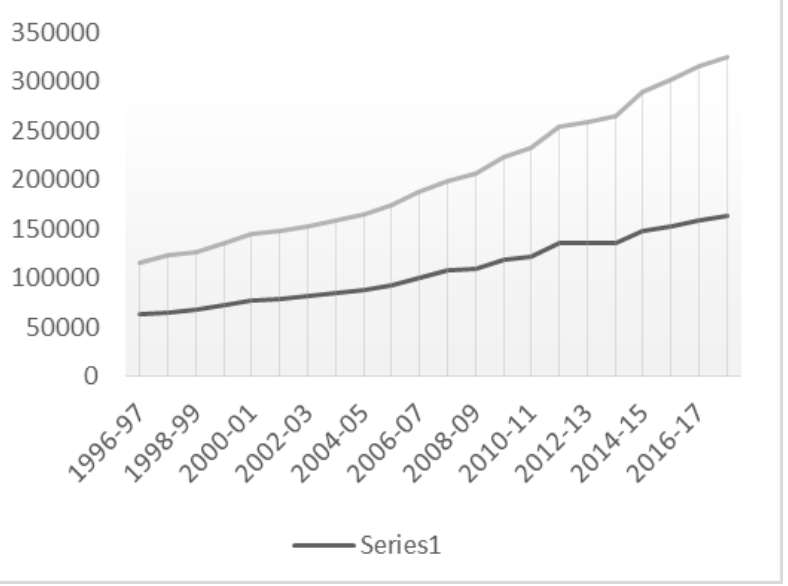

Source: Central Electricity Authority (CEA) 
Government of India and Ministry of power have been working hard to minimize the difference between the demand and supply of power since last 30 years but this has not only increased the financial burden as more than one third of our power demand is still met by thermal sources having high peak load factor (PLF) of around $24 \%$ but also heavy dependence on thermal sources has adversely affected by our environment. Excessive dependence on thermal source is shown in the figure 1.3 depicting the sources of installed capacity during planning period in XII Plan.

Figure 1.3: Sources of installed Capacity during XII plan

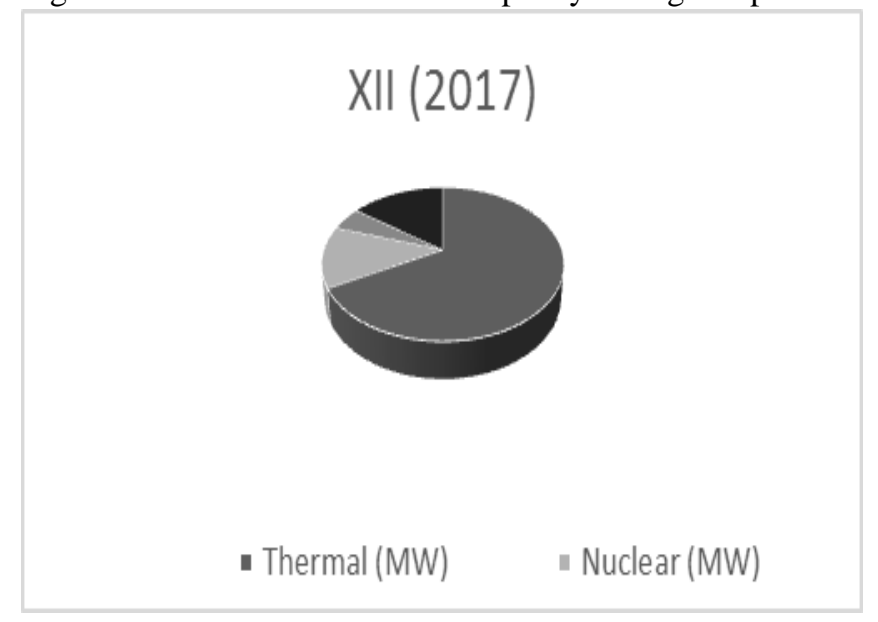

The figure 1.3 clearly highlights the fact that majority of our energy needs is met from thermal sources which is the chief contributor of greenhouse gases i.e. Sulphur dioxide (SO2), Nitrogen Oxide and these two gases contribute heavily to smog, acid rain and respiratory illness which is affecting the health of living beings and environment. Coal plants operate for a very long time and thus emit harmful gases over a long time as the amount of $\mathrm{CO} 2$ produced is the function of carbon content in the fuel. The emission of $\mathrm{CO} 2$ per unit of electricity generated from coal fired is estimated to be between 0.91 to 0.95/ per KWh (for 2000-2010) (Moti. M Mittal

\section{REVISITING SIMON KUZNETS ENVIRONMENT CURVE}

\subsubsection{Carbon Emissions from power sector:}

It is discussed in section one that more than 70 per cent of our energy demand is met from fossil fuel and it is also one of the major contributors of $\mathrm{CO} 2$ emissions resulting in climate change and global warming. Greenhouse gases are emitted in alarming rate in almost all the economies and it is very much important to device efficient strategies to reduce the emission of greenhouse gases as it would not only affect our environment but also would result in deadly diseases affecting the human development in the long run. As rightly explained by Simon Kuznets, Growth in National income would also result in increase in pollution in the initial years of development but after a certain period this increase in national income would reduce pollution in the economy as the economy would adopt green technologies which would finally reduce pollution. The Environment Kuznets Curve (EKZ) in figure 1.5 shows the relationship between environment quality and economic development. But it has been observed that in the case of many developed and developing nations that in spite of significant increase in the national income and per capita income in the last 6 decades, the pollution (Carbon emission) has not decreased as it is shown for India in figure 1.6.This has forced the researcher to look into this issue and investigate the major contributors of greenhouse gas and also find out some effective strategies so as to prove EKZ right.

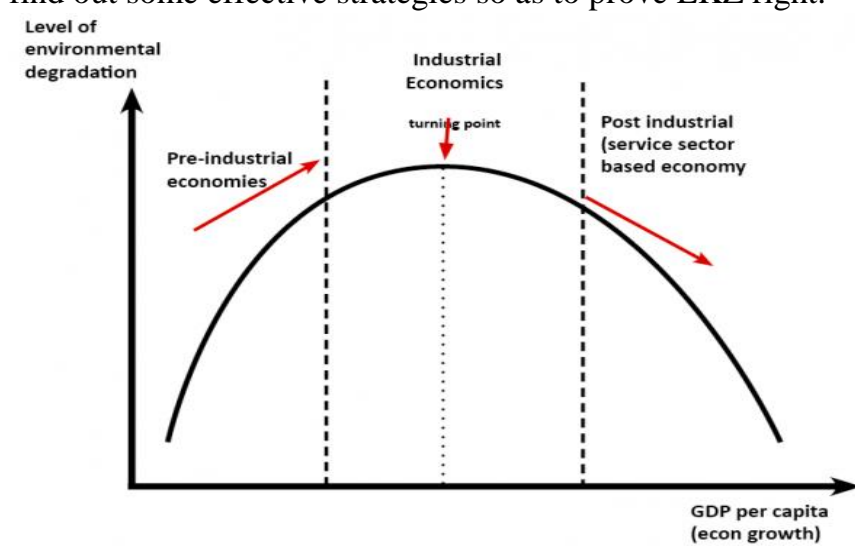

Figure 1.5: Increasing CO2 emission of India

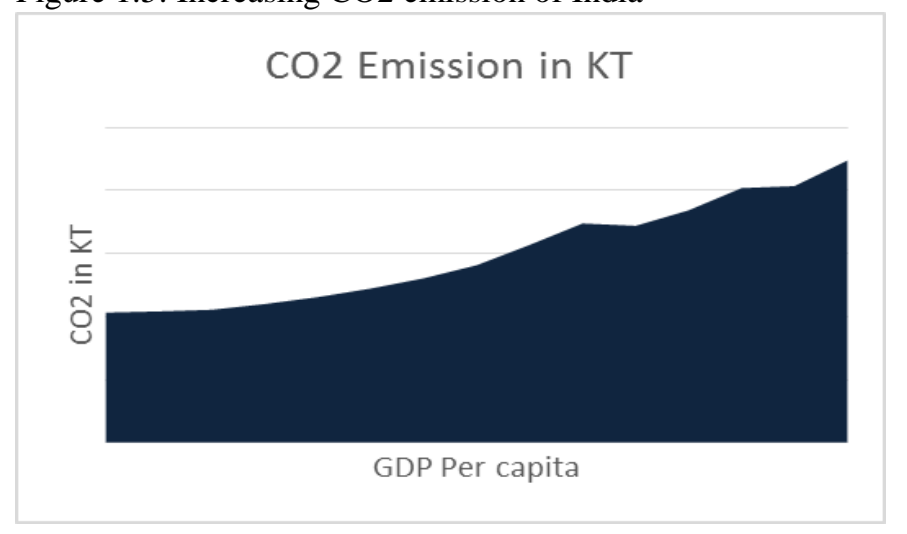

Source: World Bank Data

Figure 1.5 shows the relationship between $\mathrm{CO}_{2}$ emissions in KT from thermal power plants and GDP Per capita GDP for India from 2000 to 2017. The $\mathrm{CO}_{2}$ emission are continuously increasing at an alarming rate, therefore proving the Simon Kuznet Curve false. But it is also observed that advanced economies like USA and China through their environment friendly strategies (adopting renewable energy sources) have reduced the $\mathrm{CO}_{2}$ emissions and achieved Simon Kuznet Environment Curve i.e.an inverted U-shaped relationship between $\mathrm{CO}_{2}$ emission and GDP. Therefore, dependence on fossil fuel must be reduced or put to an end to prove Environment Kuznets Curve right.

\section{CONCLUSION AND SUGGESTION}

It is high time that all the economies should not focus only on development rather should be concerned about development without harming our environment. As discussed in section I and II our major dependence on fossil fuel especially coal has adversely affected our environment as more than 70 per cent of our energy demand is still met out from coal. It is also observed that solar, wind and hydro could not only help us to meet out our energy demand but also reduce environmental degradation largely. India is considered to have more than 300 sunny days and has the potential of 500 Trillion KWh

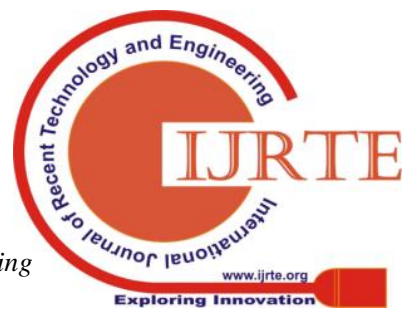


per year which is much more than the requirement. The rate of solar energy received on earth is 1, 20, 000 TW (1 $\mathrm{TW}=10^{12} \mathrm{~W}$ ) and annual global consumption is just $15 \mathrm{TW}$. This clearly brings out the fact that solar energy is the future of all the economies. Some initiatives which would help us to tap the potential of solar energy are discussed below;

a) Awareness regarding the use of solar power and its impact on environment could be spread all over especially to children through schools.

b) Financial Incentives in the form of subsidies could be extended to the individuals (residents) in order to encourage them towards the use of solar power.

c) Interest free loans to the residents to purchase Photovoltaic cells can also help people to install solar panels in the houses.

d) Installation of solar panels to be made compulsory (as rain buildings and government buildings.

e) Awards and recognition to the business unit meeting their energy demand through solar energy.

f) Encourage more research in solar energy. In case of China and USA the number of patents in Solar energy is in thousands and in case of India it is not even in hundreds. Adequate incentives for researches in the field of renewables can go a long way in achieving sustainable development goals and improve environment quality.

g) Flexible solar cells which are used by defense sector in other countries could be made commercial as to enable people to carry it anywhere in any form.

h) Investments on renewables must be increased as it is observed that advanced countries like USA and China spend more than 3 percent of their GDP on tapping the potential renewable sources and in case of India it is just 0.8 percent.

So, it is clear from the above discussion that a strong policy initiative promoting the use of renewable energy sources is the need of the hour. The suggestion put forward by the researchers would go a long way in achieving sustainable development and help the economies to fight the battle against climate change without compromising the development and growth of any economy.

\section{REFERENCES}

[1] Akshay Urja. Newsletter of the Ministry of New and Renewable Energy, Government of India 2010;4(November-December (2-3)).

[2] Kapoor K, Pandey KK, Jain AK and Nandan A (2014), "Evolution of solar energy in India: A review" Renewable and Sustainable, Energy Reviews, 40,475-487.

[3] Moti M Mittal, 2012" Estimates of Emissions from Coal Fired Thermal Power Plants in India" US Environmental Protection Agency.

[4] Ministry of Power.Available: http://www.powermin.nic.in [online].

[5] Ministry of New and Renewable Energy source (MNRE)http://www.mnre.gov.in/achievements.htm; 2015.

[6] Pandey S, Singh VS, Gnagwar NP and Vijayvergia MM (2012), "Determinants of success for promoting solar energy in Rajasthan, India" Renewable and Sustainable Energy Reviews, 16, 3593-3598.

[7] Sharma NK, Tiwari PK and Sood YR, (2012), "Solar energy in India: Strategies, policies, perspectives and future potential" Renewable and Sustainable Energy Reviews 16, 933-941.

[8] Singh A (2006)," Power sector reform in India: current issues and prospectus". Energy Policy 34:2480-90

[9] Http://www.solarindiaonline.com/solar-india.html\#present.

[10] Jawaharlal Nehru National Solar Mission (MNRE) Website of Ministry of New \& Renewable Energy, Government of India, water harvesting in some states) for all the commercial

[11] http://mnre.gov.in/; 2015.

[12] http://www.eai.in/ref/ae/sol/sol.html

[13] Veeraboina P and Ratnam GY (2012), "Analysis of the opportunities and challenges of solar water heating system (SWHS) in India: Estimates from the energy audit surveys \& review" Renewable and Sustainable Energy Reviews, 16, 668-676

[14] Shahbaz, M., Sinha, A.: "Environmental Kuznets Curve foe co2 emissions: a Literature Survey". Journal of Economic studies vol. 46.1. Emerald group Publishing LTD., UK (2019)106-168

[15] Dinda, S., Environmental Kuznets Curve Hypothesis: A Survey. Ecological Economics vol.49. Elsevier BV., Netherlands (2004)431-455

[16] International Energy Agency Outlook (2011) annual report

[17] The New York Times (Jan. 25 ${ }^{\text {th }}$,2017); China's emission s more than U.S plus Europe, and still rising Manuel, A. Zambrano-Monserrate, Christopher Carvajal-Lara \& Roberto Urgiles-Sanchez.: Is there an inverted U-shaped Curve? Empirical analysis of the Environmental Kuznets Curve in Singapore. Asia Pacific Journal of Accounting and Economics. Vol 25,1-2, Taylor and Francis., UK (2018)145-162

[18] Ahmed, K., Long,W: An empirical analysis of co2 emission in Pakistan using EKC hypothesis. Journal of International Trade Law and Policy, vol. 12. 2. Emerald group Publishing LTD., UK (2013)188-200

[19] V.G.R. Chandran Govindaraju and Chor Foon Tang (2013); The dynamic links between $\mathrm{CO} 2$ emissions, economic growth and coal consumption in China and India

[20] U.S. Energy Information Administration. U.S. energy -related $\mathrm{co} 2$ emission fall 1.7\% in 2016 (eia, Independent Statistics and Analysis). Washington DC U.S. (2017): Perry Lindstrom

[21] International Energy Association. Latest trends in $\mathrm{CO}_{2}$ emissions (Global Energy and $\mathrm{CO}_{2}$ status report). Paris, France (2018)

[22] Corinme,L.Q., Anand, M.,Oliver, B.,Gail, W., Glen P.,\& Dabog: Emission are still rising: ramp up the cuts. Nature International Journal of Science. vol.564. Springer Nature (2018) 27-30.

[23] Roberts, J. T.\& Grimes, P. E.:Carbon intensity \& Economic development 1962-91: A Brief exploration of the environmental Kuznets Curve. World Development, vol,25. 2. Elsevier Science ltd. (1997) 191-198.

[24] Kunnas, J., Myllyntaus,T.: The Environmental Kuznets Curve Hypothesis and Air pollution in Finland.

[25] Scandinavian Economic History Review. Vol 55. 2. Taylor and Francis, UK (2007) 101-127

[26] Nain, Ahmad and Kamaiah: Economic growth, Energy consumption and $\mathrm{CO} 2$ emissions in India (2017). International Journal of Sustainable Energy, Vol. 36:8, p. 807-824.

[27] Bhat and Mishra: Indian growth and Development Review, Kyoto protocol and $\mathrm{CO} 2$ emission vol. 11 Issue 2, pp. 152-168

[28] Xu Guangyue \& Song Deyong: An Empirical Study on the Environmental Kuznets Curve for China's Carbon Emissions Based on Provincial Panel Data, Chinese Journal of Population and Environment. 9:3, 66-76.

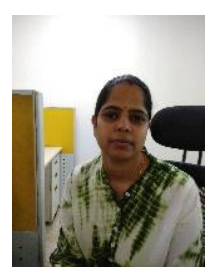

\section{AUTHOR's ProfiLe}

Dr Oum Kumari R, Assistant Professor has done her graduation and Post-Graduation from University of Madras. She also is a university Rank Holder in BA Economics Hons. She pursued her M. Phil from Presidency College and $\mathrm{PhD}$ from Malaviya National Institute of Technology. Research in the Areas of Energy Management and Renewables has been taken up in last ten years. Twelve articles in reputed journals has been published and Book Chapters in the area of Finance is also to her credit.

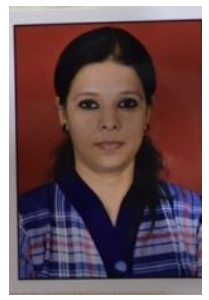

Dr Nupur Ojha, currently Assistant Professor a Manipal University Jaipur, has done her graduation and Post-Graduation from University of Rajasthan She completed her Phd in Rural Finance from Maharaja Ganga Singh University, Bikaner. With an overall work experience of 14 years, she is currently working in the area of Sustainable development. 